Article

\title{
A Shear Reynolds Number Based Investigation Method of the Bed Load Transport in Large Rivers with Complex Morphodynamics
}

\author{
Gergely T. Török ${ }^{1,2, *}$, János Józsaa, ${ }^{1,2}$, Sándor Baranya ${ }^{2}$ \\ 1 MTA-BME Water Management Research Group; torok.gergely@epito.bme.hu \\ 2 Department of Hydraulic and Water Resources Engineering, Faculty of Civil Engineering, \\ Budapest University of Technology and Economics; baranya.sandor@epito.bme.hu \\ * Correspondence: torok.gergely@epito.bme.hu; Tel.: +36-1-463-2248
}

\begin{abstract}
The aim of this study is to introduce a novel method which can separate sand or gravel dominated bed load transport in rivers with mixed-size bed material. In engineering practice, the Shields-Parker diagram could be used for such purposes, however, the method has certain applicability limits, due to the fact that it is based on uniform bed material and provides information rather on river-scale, instead of reach or local scale. When dealing with large rivers with complex hydrodynamics and morphodynamics the bed load transport modes can also indicate strong variation even locally, which requires a more suitable approach to estimate the locally unique behavior of the sediment transport. Here, we suggest that the decision criteria utilizes the shear Reynolds number $\left(R e^{*}\right)$. The method was verified against field and laboratory measurement data, both performed at non-uniform bed material compositions. The comparative assessment of the results show that the shear Reynolds number based method operates more reliably than the Shields-Parker diagram and it is expected to predict the sand or gravel transport domination with a $<5 \%$ uncertainty. The introduced results can greatly contribute to the improvement of numerical sediment transport modeling as well as to the field implementation of bed load transport measurements.
\end{abstract}

Keywords: bed load transport, shear Reynolds number, mixed-size bed material, complex morphodynamics

\section{Introduction}

In terms of typical geomorphological features, rivers can be divided into three main section types: upper, middle and lower course [1]. One of the decisive differences among these river features is the erosion capacity of the flow, which constantly decreases along the river. In fact, it can be stated that the erosion prevails along the upper course rivers, yielding coarser gravel bed material and significant bed load transport. As to the middle course, all the three characteristic sediment transport processes, such as the local erosion of the bed, the transport of coarse and fine particles together with river bed aggradation take place, resulting in a dynamic equilibrium of the river. Finally, the lower course type rivers can be generally characterized with the deposition of fine sediments transported from upstream. Due to the spatially and temporally varying erosion capacity of the flow and the changing river planforms (straight, meandering or braided river channel patters [2]), the morphological features also show significant variability.

Many classification methods can be found in the literature to describe the morphological properties of river sections (e.g. [3-7]). The main goal of these tools is to typify and predict the dominant morphological properties and processes, such as to define the predominant sediment transport mode (bed load, or suspended load) [8], the channel pattern type [1,9], the specific bed material grain size [7], the erosion capacity [10], or the bed armor measure [6] etc. According to these 
methods, the morphological properties and processes can be estimated as the function of a few, easily definable hydro-morphological variables, e.g. the water depth, the channel width, the mean flow velocity, the mean grain size of the bed material, or the longitudinal bed slope.

For instance, there are classification methods, suggesting that the dominant grain size of the bed load (sand or gravel) can be obtained based on the river course type (e.g. the Shields-Parker diagram, [8]). In most cases, such a classification is straightforward due to the fact that a dominant bed material fraction can be easily chosen, considering e.g. sand-bed $\left(d_{50}<2 \mathrm{~mm}\right)$ or gravel-bed $\left(d_{50}>\right.$ $2 \mathrm{~mm}$ ) streams [8]. However, there are several situations, when such a clear distinction cannot be made as both sand and gravel dominated zones appear even in shorter river reaches. Moreover, the locally dominant fraction can alter according to the current flow conditions. So, only the motion of finer particles of a non-uniform bed material can occur during low-water regime. In turn, the higher flood waves increase the sediment transport capacity of the flow, resulting in probably gravel dominated bed load.

These sections are typical to middle course rivers, at the transition sections in terms of bed material. Here, the flow pattern can easily result in spatially strongly varying bed material composition (e.g. coarse river bed surface in the main stream, sand dominated zones in shallower parts). As the bed load is mainly fed by the alluvium [11], strongly different grain sizes can characterize the bed load transport.

Such a typical river reach is the upper Hungarian Danube reach between rkm 1798 and rkm 1795 (Fig. 1). At this section, the middle course resulted in a meandering pattern type, with non-uniform bed material ( $d_{50}$ ranges between $0.32-70.5 \mathrm{~mm}$ ) $[9,12]$. Furthermore, conventional river regulation measures (e.g. groin fields) were installed, which further enhanced the diversity of the morphological properties and processes [13-17]. The following parameters characterize the river: the main channel width at mean water regime ranges between $150 \mathrm{~m}$ and $350 \mathrm{~m}$; the average water surface gradient is around 0.0002-0.00025 [16], whereas the characteristic flow discharges are $Q_{m}=$ $2000 \mathrm{~m}^{3} / \mathrm{s}$ (mean flow), $Q_{b f}=4300-4500 \mathrm{~m}^{3} / \mathrm{s}$ (range of bankfull discharge), $Q_{100}=10400 \mathrm{~m}^{3} / \mathrm{s}$ (100-year flood event) [18] and $Q_{200}=\sim 10800 \mathrm{~m}^{3} / \mathrm{s}$ (200-year flood event) [19]. Here, the dominant fraction in the bed material and hence in the bed load shows a strongly varying spatial distribution. That is, bed armoring and gravel bed load takes place in the main channel, while the aggradation and erosion of the fine particles can be observed in the near-bank zones and in the groin fields. And finally, the accumulation and erosion of the gravel and partly the sand is detectable at some places, resulting in the formation of side bars (Fig. 1).

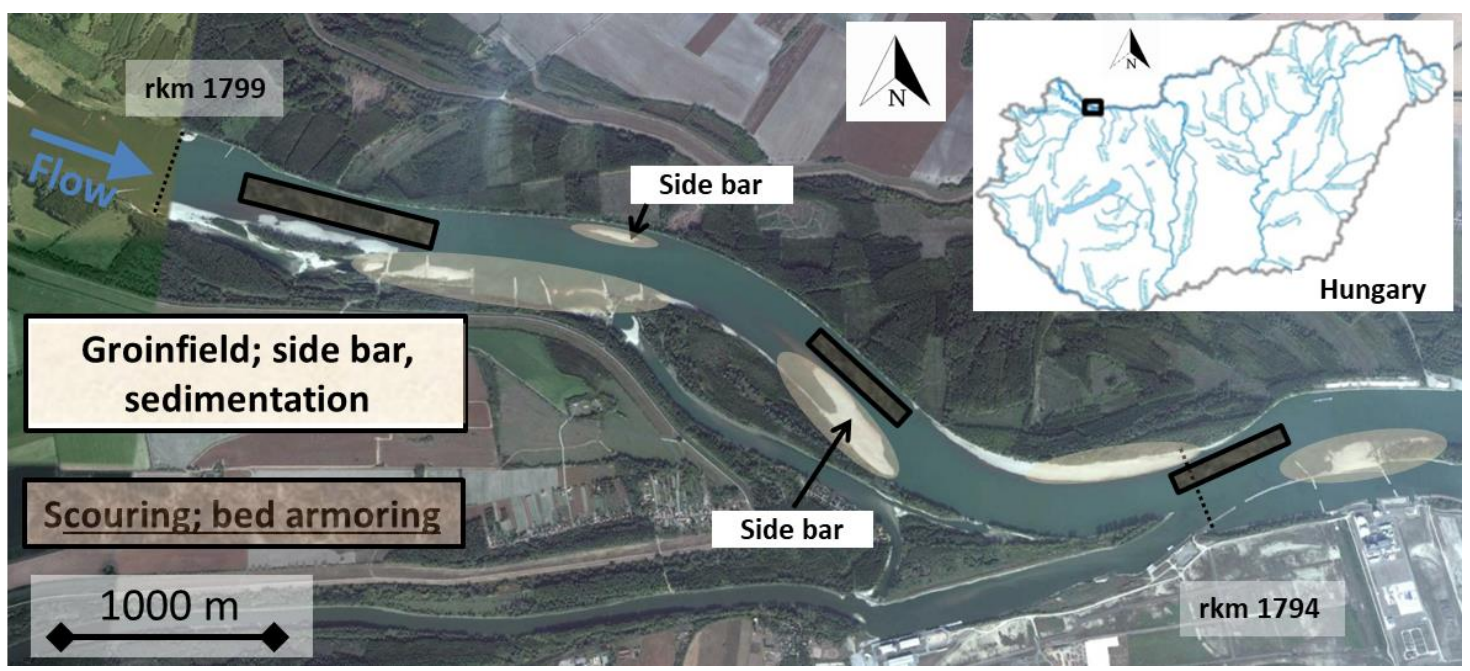

Figure 1. The sketch of the investigated section of the Danube River.

The herein presented study focuses on this issue: how can the dominant fraction of the bed load transport be determined, when both the river hydrodynamics and the morphological features show strong inhomogeneity within the studied reach. When local or reach scale morphodynamic analysis is carried out it is far not evident what sort of empirical sediment transport formula is to be used, 
locally. There can be found formulas for finer, such as sand fractions (e.g. [20]), as well as for coarser, rather gravel dominated fractions (e.g. [21]), both having limitations when considering mixed-size bed material. In fact, if the dominant fraction in the bedload could be reasonably estimated, the suitable formula for the assessment of morphodynamic processes could be more accurately performed. To the authors knowledge, no such straightforward method can be found in the literature, which suggests the dominant bed load transport mode for non-uniform bed material. An attempt is made in this study to fill this gap, providing a methodology, which works more accurately compared to earlier published methods.

\section{Problem statement}

The numerical simulation of morphodynamic processes in rivers play a crucial role in several river engineering activities, e.g. when planning restoration measures, and considered as a widely applied investigation tool with many benefits. However, the reliable numerical description of the interaction between river hydrodynamics and the morphological features is a very challenging task in rivers with uniform bed material composition, but shows even higher difficulties in case of mix-sized bed material conditions (e.g. [22-26]). When the grain sizes cover a smaller range in the bed material, the potential erosion results also in a quite uniform grain size range of the bed load transport. For such conditions, many sediment transport models have already been developed and successfully validated [27-30]. On the other hand, in case of inhomogeneous river bed material, the characteristic grain sizes in the bed load transport can significantly change both in time and space. The reliable numerical description of such a variability is still a challenge, which sets back the accuracy of the sediment transport calculation possibilities.

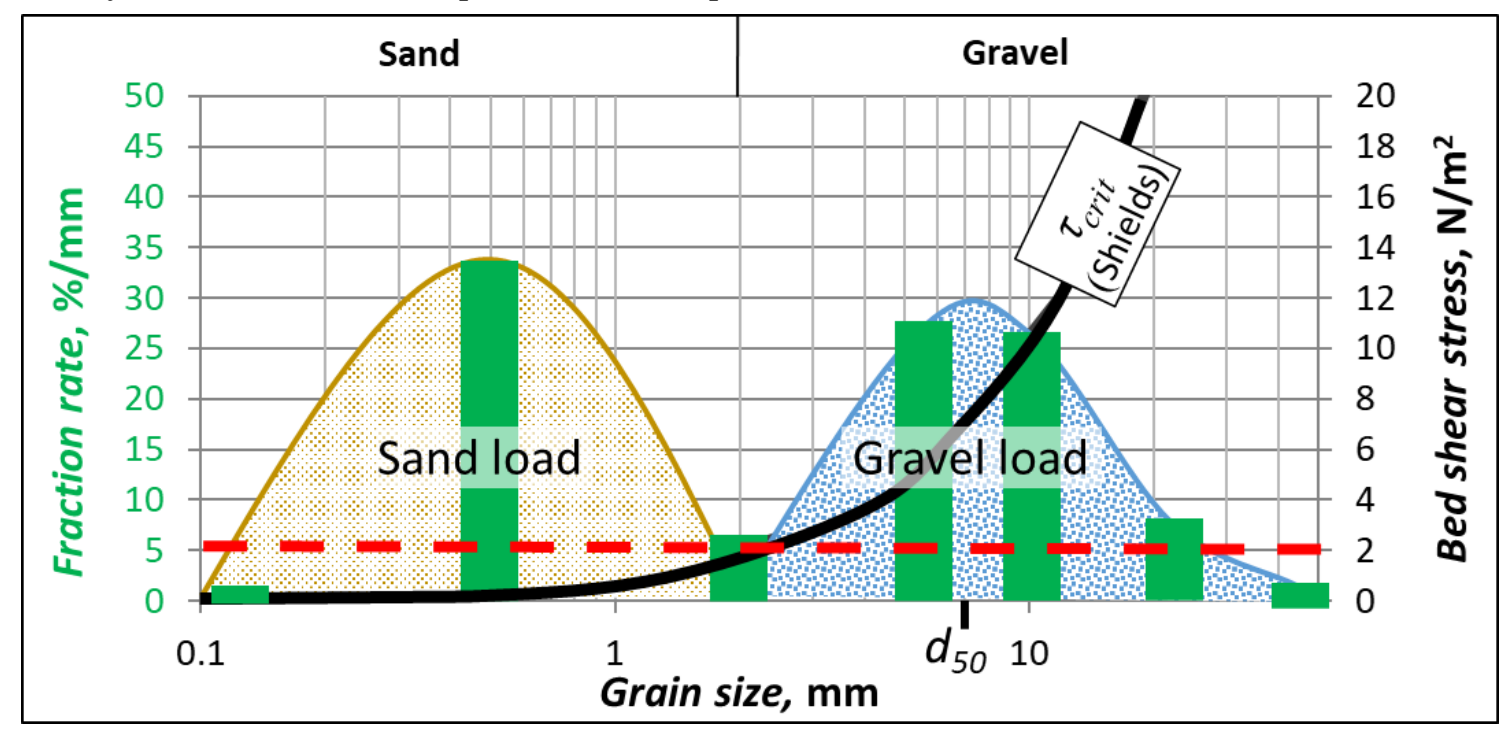

Figure 2. The density function of a bed material sample collected from a side bar (green curve). The Shields curve related critical bed shear stress values are depicted by the black line.

Significant variability of the dominant grain size in the bed load can take place in non-uniform bed material, e.g. in case at the investigated Danube reach. Fig. 2 shows the density function of a bimodal bed material sample, collected from the lower side bar (see Fig. 1). As the fraction rates indicate, sand and gravel also appear well separately, both with significant amount $(>30 \%)$. The grain size distribution indicates a $d_{50}$ of $7 \mathrm{~mm}$, which would refer to gravel transport. However, examining the critical bed shear stress values (calculated by the Shields curve, black line) the dominant bed load grain size seems not to be constant, but rather dependent on flow conditions. If the flow erosion capacity $(\tau)$ is in a lower range (e.g. $\left.<2 \mathrm{~N} / \mathrm{m}^{2}\right)$, only sand $(<2 \mathrm{~mm})$ movement can be expected. In turn, increasing bed shear stress $\left(>2 \mathrm{~N} / \mathrm{m}^{2}\right)$ results in the motion of even the coarser gravels $(>2 \mathrm{~mm})$, while the motion of the finer sand fraction trends to be rather suspended like rolling [8], resulting in even coarser bed load. Concluding the above, the $d_{50}$ grain size of the bed 
material is not able to indicate the current dominant grain size in the bed load, especially not in case of non-uniform bed material under varied flow conditions.

Based on the previously presented example it can be stated that because of the local flow features and local bed material composition, the dominant fractions in the bed load can easily vary from sand to gravel even in shorter sections [16,31]. When performing morphodynamic analysis of river reaches, it is a relevant question, how to predict if the sand or rather the gravel transport dominates the sediment transport locally? Because of the available methods cannot be applied for such purposes, it has to be enhanced that a novel approach is needed to identify locally dominant sediment transport nature, when focusing on spatially and temporary varying flow and morphological features at shorter river sections.

\section{Approach}

As one applicable method, the Shields-Parker river sedimentation diagram can be used as a comprehensive bed-material and sediment transport nature classification tool for a particular river reach, with uniform bed content [7]. The diagram indicates the Shields number ( $\tau^{*}$, or equivalently $\tau^{*} b f$, Eq. 1) based on the $d_{50}$ specific mean grain size versus the so called explicit particle Reynolds number ( $R e_{p}$, Eq. 2). The diagram includes the well-known Shields curve (continuous black curve), which shows if the given particle is in motion (points above the curve), or remains still on the bed surface (points below the curve).

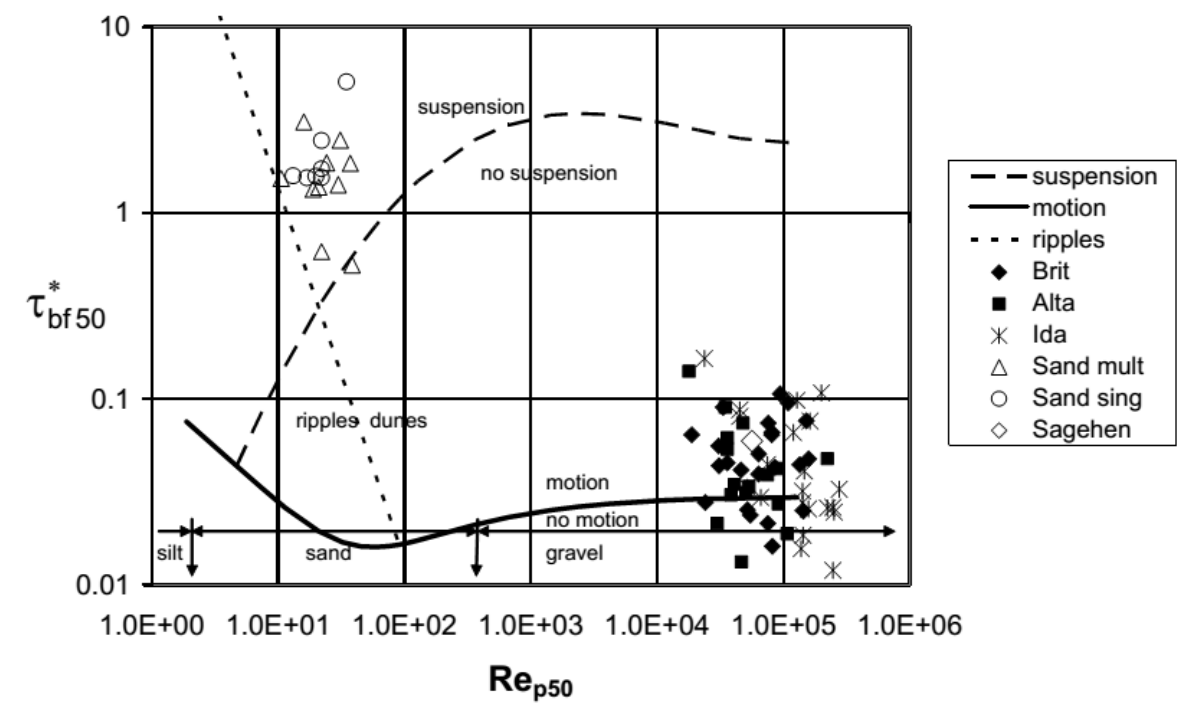

Figure 3. Shields-Parker river sedimentation diagram [7].

Parker stated [8], that alluvial rivers can usually be divided into two types as the function of $R e_{p}$, (which can, in fact, be considered as the dimensionless substitution of the grain size): sand-bed and gravel-bed rivers. According to his research, a distinction can be defined exactly based on $R e_{p}$, which actually depends only on $d_{50}$. That is, considering that $d=0.002 \mathrm{~m}$ is the threshold value between the sand and gravel fractions, the critical value for $R e_{p}$ also can be calculated according to Eq. 2, where $d$ $=0.002 \mathrm{~m}$ results in $R e_{p}=360\left(R e_{p}>360 \rightarrow\right.$ gravel bed, $R e_{p}<360 \rightarrow$ sand-bed $)$, which critical value is depicted by a vertical narrow in Fig. 3, within the $R e_{p}$ range of $100-1000$.

$$
\tau^{*}=\frac{\tau}{g\left(\rho_{s}-\rho_{w}\right) d},
$$

where $\tau^{*}$ is the Shields number, $\tau$ is the bed shear stress, $g$ is the acceleration due to gravity, $\rho_{s}$ is the sediment density, $\rho_{w}$ is the water density and $d$ is the grain diameter.

$$
R e_{p}=\frac{\sqrt{g R d} d}{v},
$$

where $R=\left(\rho_{\mathrm{s}}-\rho_{W}\right) / \rho_{W}, \rho_{W}$ is the water, $\rho_{s}$ is the sediment density and $v$ is the kinematic viscosity of the fluid. 
Consequently, the method basically yields a grain size based classification method for near uniform bed materials. This simplified approach is not capable to classify characteristic local morphodynamic processes for complex situations in terms of river bed morphology and inhomogeneous bed material composition though [7] (e.g. in case of bed material like Fig. 2).

The basic idea here is to keep the simplicity of the classification method shown by Parker, but at the same time to involve a new indicator, which accounts for the local hydrodynamic effects that better characterize the interaction between the water flow and the river bed, i.e. the erosion capacity. Thus, based on literature review, field and laboratory measurements, a conjecture is introduced in this paper. The most relevant findings of the related publications are summarized in the followings.

Shields published a well-known study regarding sediment transport investigation in 1936. Based on experimental results, Shields pointed out that the stability of the grain and the inception of motion depends not on the grain size, but also on the hydraulic flow regime around the grain, which can be expressed by $R e^{*}$.

$$
R e^{*}=\frac{u_{*} d}{v},
$$

where $u^{*}$ is the shear velocity $\left(u_{*}=\left(\frac{\tau}{\rho}\right)^{0.5}\right.$, where $\tau$ is the local bed shear stress).

The paper also emphases that the benchmark measurements were elaborated for hydraulic smoother $\left(R e^{*}<500\right)$ regime.

As one of the most widely tested and applied sediment transport formulas for river engineering applications, the van Rijn bed load transport equation [20] also considers the application of the Shields curve. The transport model was developed and validated for sand fractions, and so the application limit was defined accordingly $(d<2 \mathrm{~mm})$ [7]. However, Parker pointed out [8] that at higher hydraulic rough regime the motion of the sand fractions is rather suspended like rolling. Therefore, a more accurate calculation of the sand motion is expected by a suspended sediment transport formula instead of a bed load formula, in hydraulic rough regime. That is to say, the grain size is not able to determine correctly the application limits of the formula. However, the $R e^{*}$ values regarding to the calibration $\left(R e^{*}<\sim 100\right)$ and validation $\left(R e^{*}<\sim 400\right)$ measurements $[20,32,33]$ suggest that the van Rijn bed load model is valid for hydraulic smoother regime. Although it was not exactly defined, van Rijn mentioned [20] that the model is valid only for lower $R e^{*}$.

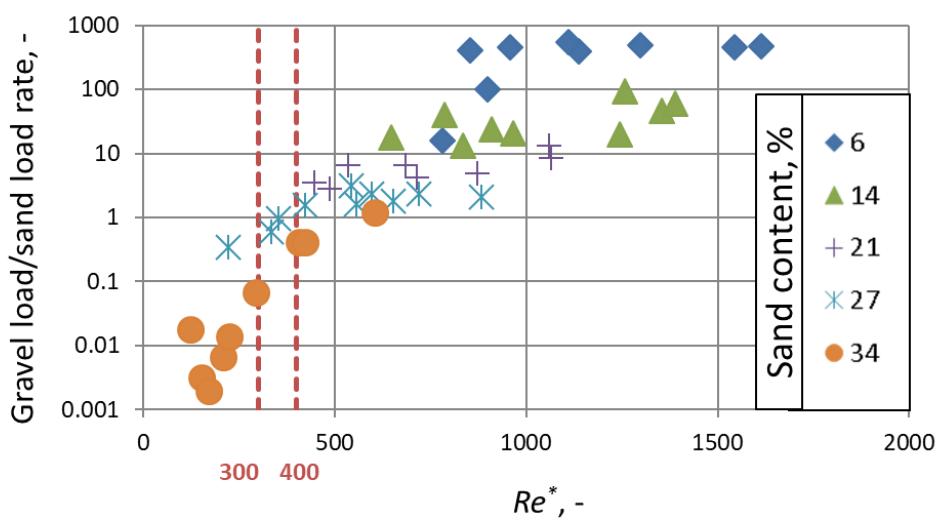

Figure 4. Calculated rates of the gravel load to the sand load as the function of the shear Reynolds number, based on the laboratory experiments of Wilcock et al. [23].

The laboratory experiments, where non-uniform bed material conditions were investigated by Wilcock et al. [23] (for which the Wilcock and Crowe [21] bed load transport formula was developed and validated) is also taken into consideration here. Fig. 4 shows the rate of the gravel load to the sand load as the function of the $R e^{*}$. The coloring of the points refers to the sand content of the initial mixture. Within any mixtures the higher the $R e^{*}$, the coarser the composition of the bed load. A clear behavior can be noticed: in case of the same mixtures, at lower $R e^{*}$ only the finer part of the bed material is being transported, but at higher $R e^{*}$ gravel load dominates. It is also visible that the gravel 
load is equal to the sand load when the $R e^{*}$ is between 300 and 400 , around 350 (Fig. 4). Thus, $R e^{*} \approx$ 350 seems a critical value; above this the gravel transport is dominant. In turn, below 350 the sand transport prevails, which underlines the earlier assumption that the fine sediment bed load transport happens and dominates in the hydraulic smoother range.

In order to confirm the conjecture, an assessment, considering characteristic local bed grain sizes, local bed shear stress values as well as calculated Reynolds numbers, was performed, using datasets from recent laboratory and field experiments of the authors. First, the results from the laboratory experiments of Török et al. [34] were used. In this experiment, morphological processes (scouring, bed armoring and aggradation) were investigated around a single groin, using mixed size bed material with an initial $d_{50}$ of $5.16 \mathrm{~mm}$. The local grain size distributions were determined by an automated image based grain detection software tool BASEGRAIN [35]. Local bed shear stress values were estimated according to the TKE-Method [36] using the near-bed point-velocity measurements, carried out with a 3D Acoustic Doppler Velocimeter (ADV) [37]. The measurements were carried out at quasi-equilibrium bed geometry. Then, negligible bed changes were measured in the flume $\left(\Delta_{z}< \pm 1 \mathrm{~mm} / \mathrm{h}\right)$, however weak bedload transport $\left(Q_{b}<0.3 \mathrm{~kg} / \mathrm{h}\right)$ of mainly the sand particles $\left(d_{50}=1.3 \mathrm{~mm}\right)$ could be still observed at the outlet of the flume, where the $d_{50}$ of the bed material ranged between 4 and $6 \mathrm{~mm}$ [34].

Second, field data from a section of a large river was also assessed. The field experiments were carried out in the Hungarian section of the Danube River at mean flow regime, where the main characteristic morphological parameters were already introduced in the Introduction point. 47 bed material samples were taken by a drag-bucket sampler, for which, the grain-size distributions of the samples were determined by sieving analysis. Parallel to the bed material samplings local, time-averaged flow velocity profiles were measured by an acoustic Doppler current profiler (ADCP) (WorkHorse Rio Grande $1200 \mathrm{kHz}$ ) at the sampling locations. Based on these long-term, fixed boat measurements, the local bed shear stress values could be estimated using the turbulent wall law [38]. No bed load sampling could be performed at during the two measurement campaigns. However, the bed load rating curve at the closest monitoring station (6 km upstream) [39] represents that low but not negligible bed load transport took place during both measurements $\left(Q_{b}<0.1 \mathrm{~kg} / \mathrm{s}\right)$.

\section{Results}

Based on the above described summary, the following important findings are emphasized:

- Shields has already presented [30], that the shear Reynolds number $\left(R e^{*}\right)$ can be a suitable variable (instead of the grain sizes) to classify the sediment transport in the near-surface zone. In other words, the flow conditions (together with the bed material features) must be taken into account for the proper investigation of the stability and mobility of bed forming particles. Moreover, the published results suggest that the sand bed load occurs at lower $R e^{*}$ range, $R e^{*}<$ $\sim 500$.

- The investigation of the measurements, for which the van Rijn bed load formula was validated and calibrated [20,32,33] suggest that the sand bed load can occur at lower $R e^{*}$ range, $R e^{*}<400$. Complementing this by the statement of Parker [8] it is assumed that in rougher hydraulic regime $\left(R e^{*}>\sim 1000\right)$, the sand transport appear only in suspended form, while the bed load consists mainly of gravel.

- The $R e^{*}$ based assessment of the laboratory experiments of Wilcock et al. [23] shows that the $R e^{*}$ range $\sim 3-400$ seems to be a critical zone, where the yield of the sand and gravel are roughly the same. A characteristic grain size cannot refer to such phenomena.

Accordingly, the following conjecture was stated: The $R e^{*}$ parameter is a more suitable parameter for the prediction and distinction of the sand or gravel dominated bed load transport, than either simply a characteristic grain size $\left(d_{90}\right.$ or $\left.d_{50}\right)$, or the $R e_{p}$, when spatially strongly varying morphological features are present. Moreover, $R e^{*}$ range $\sim 3-400$ seems to be a critical zone: above the gravel, below the sand domination can be expected in the bed load. 
Laboratory and field experiments were conducted to verify the conjecture. First, the field data from the above introduced reach of the Danube River in Hungary is presented.

At the investigated Danube site, the $d_{50}$ grain size in the river bed ranges between 0.32 to 70.5 $\mathrm{mm}$. The estimated local bed shear stress values increase with higher grain sizes, however, quite significant scattering of the points can be seen (Fig. 5). The green triangles refer to the sandy bed material samples, which were collected from the near-bank zones. Here, the bed material consists predominantly of silt and sand, gravel transport can be expected only during flood waves. The blue points originate from the side bars (e.g. bed material illustrated in Fig. 2). As it was introduced in chapter 2 and based on Fig. 2, the dominant grain size in the bed load is variable (both the sand and gravel can also dominate) and strongly flow dependent. Finally, the samples from the main channel are depicted by the red symbols. Based on the bed material analysis, only gravel transport can occur at this region of the channel, because the sand can be vanishingly found. But as the measurements indicate very stable bed surface, pure gravel transport can be expected.

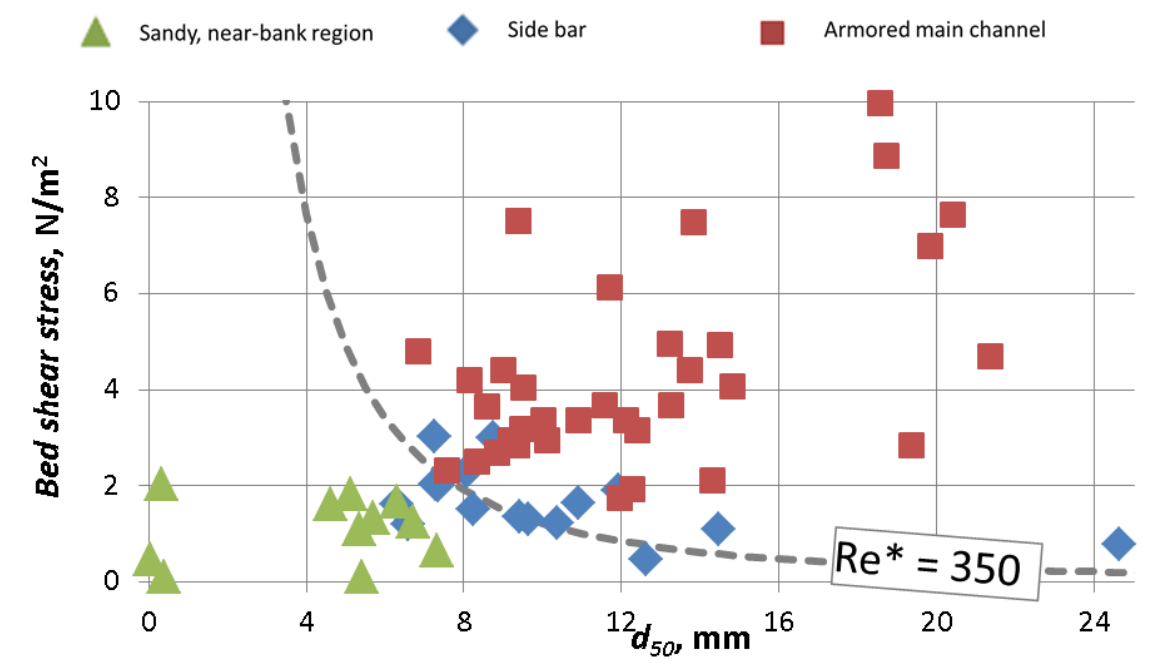

Figure 5. The bed shear stress as the function of the $d_{50}$ grain size, regarding to field and laboratory measurements $[16,31,34,38]$

Nevertheless, when indicating a separation line, which represents a $R e^{*}$ of 350, the points from the three well distinguishable regions indeed show different features. Points representing the shallower, sandy regions fall below the line. As most of these sampling locations can be characterized with mean grain sizes in the gravel range, $\left(d_{50}>0.002 \mathrm{~m}\right)$, the Shields-Parker diagram would consequently suggest clear gravel transport. However, considering the relatively low bed shear stress values $\left(<2 \mathrm{~N} / \mathrm{m}^{2}\right)$, the Shield-curve predicts only sand motion (see the findings based on Fig. 2). Indeed, the $d_{50}$ of the bed material samples at the outlet of the flume $(4-6 \mathrm{~mm})$ would refer to gravel domination in the bed load, but the corresponding $d_{50}$ of the bed load samples show clear sand domination $(1.3 \mathrm{~mm})$ [34].

Second, the points distributed along the line belong to the bars. This part of the points is presumably in critical transitional state, where the sand or gravel domination cannot be well distinguished, but most probably a similar amount is transported. Accordingly, two phenomena can occur: i) the bed shear stress values are low and the bed materials are quite uniform and coarse, resulting in resting particles (blue dots, $\tau<\sim 1 \mathrm{~N} / \mathrm{m}^{2}$ ); ii) higher flow transport capacity can cause almost the same order of magnitude in the sand and gravel discharge, if the bed material contains both fractions (blue dots, where $\tau>\sim 2 \mathrm{~N} / \mathrm{m}^{2}$ and see also Fig. 4.).

Finally, the points located above the line represent the stable $[16,31,34,38]$ main stream with coarse grains. Because of the armored bed surface, weak sediment transport occurs during mean flow discharge. Only higher flood waves can result in significant bed load transport [38], containing of the local bed material, i.e. only gravel grains.

Assessing the relationship between local Shields number and the shear Reynolds number for both the laboratory and field experiments (Fig. 6 A), it can be stated that there is a correlation 
between the $R e^{*}$ and the local sediment transport nature: the higher the $R e^{*}$ number the more dominant the coarser grains in the local sediment transport nature. In turn, the lower the $R e^{*}$ the more prevailing process is the sand motion. Furthermore, it can also be observed that the $R e^{*} \approx$ $300-400$ is a suitable indicator for the identification whether the gravel (coarsening, scouring and bed armoring) or rather the sand (aggradation, erosion) particles dominated processes take place, in case of non-uniform bed material. No clear distinction of the dominating morphodynamic processes can be made if the particle Reynolds number is considered (Fig. 6 B), as most of the points, representing all the three different transport modes, range between $1000<R e_{p}<10000$, clearly below the critical condition provided by Shields. Accordingly, a stable bed surface is expected both in the laboratory and in the field study. However, this is only the case for the armored sections of the study sites (red points in Fig. 6) $[16,31,34,38]$, whereas the bed load measurements of the laboratory experiments and the bed load rating curve at the study site in the Danube River demonstrate that week bed load transport took place in both cases. Moreover, the bed load material investigation of the laboratory experiment suggested that the bed contained mainly sand fractions. Overall, despite the fact that the Shields curve would suggest stable bed, week and sand dominated bed load transport took place during the field and laboratory measurements.

Concluding the above findings, the $R e^{*}$ based analysis of the bed material samples, an improved understanding of the local bed load transport can be gained. That is, if bed load transport can be detected at a given region of a morphodynamically complex river reach, the locally dominant grain size of it can be estimated as the function of the Re*. Looking at the results from the experiments (Fig. $6 \mathrm{~A}$ ), mainly sand motion can be expected in the bed load transport in the near-bank zones (green triangles). In turn, only gravel motion can occur in the main channel, if the transport capacity of the flow is high enough at all (see the red dots). Furthermore, a transition character, in terms of the composition, is shown for the side bars (blue dots).

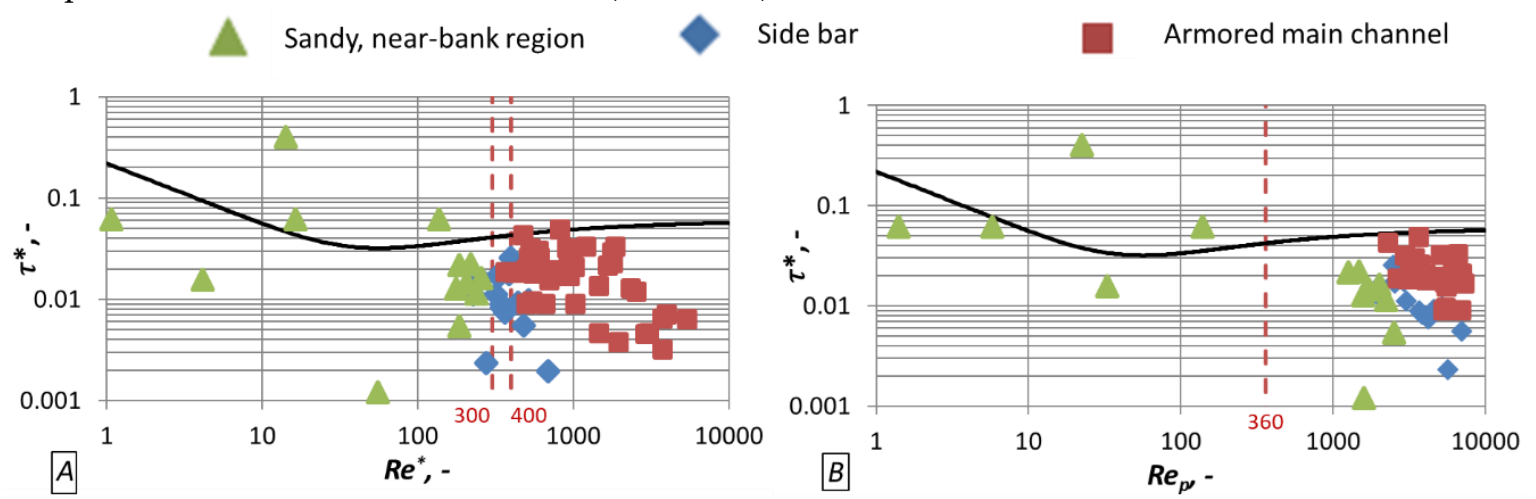

Figure 6. A: Shields number as the function of the shear Reynolds number, based on laboratory and field data $[16,31,34,38]$. Shields curve is indicated with black line.

B: Shields number as the function of the explicit particle Reynolds number, based on laboratory and field data $[16,31,34,38]$. Shields curve is indicated with black line.

In order to perform a quantitative assessment on the performance of the $R e^{*}$ based approach, a statistical method was applied, which provides information on the representativity of the Reynolds number ranges for the characteristic bed load transport processes. Here, the log-normal distributions of the $R e^{*}$ and $R e_{p}$ values were calculated, separately for the three above distinguished groups. The reason for using the log-normal distribution was the fact that asymmetric distributions were expected (based on the scatters of the points), where Re numbers cannot take negative values [40]. The probability density for the log-normal distribution is expressed as:

$$
P(x)=\frac{1}{(x-\gamma) \sigma \sqrt{2 \pi}} e^{-\frac{1}{2}\left(\frac{\ln (x-\gamma)-\mu}{2 \sigma^{2}}\right)^{2}},
$$

where the parameters are $0 \leq \gamma<x$ (location parameter), $-\infty<\mu<\infty$ (scale parameter) and $\sigma>0$ (shape parameter), can be obtained by the fitting of the function to the known points. The integration of the log-normal distribution curves results in the cumulative distribution function, which is: 


$$
F(x)=\Phi\left(\frac{\ln (x-\gamma)-\mu}{\sigma}\right)
$$

where $\Phi$ is the Laplace integral $[41,42]$.

As a summary of the calculations, the probability data was summarized for the six log-normal distributions, considering $R e^{*}=300, R e^{*}=400$, and $R e_{p}=360$ as critical values.

Table 1. Probability values of the shear Reynolds number and the particle Reynolds number, calculated based on the fitted log-normal distribution for grouped data.

\begin{tabular}{cccc|cc} 
& \multicolumn{3}{c}{$\boldsymbol{R e}^{*}$} & \multicolumn{2}{c}{$\boldsymbol{R e}_{p}$} \\
\cline { 2 - 6 } & $<300$ & $<>$ & $>400$ & $<360$ & $>360$ \\
\hline $\begin{array}{c}\text { Sand aggradation, } \\
\text { near-bank points }\end{array}$ & $\mathbf{9 5 \%}$ & $5 \%$ & $0 \%$ & $15 \%$ & $85 \%$ \\
\hline Side bar & $5 \%$ & $\mathbf{6 0 \%}$ & $35 \%$ & $0 \%$ & $100 \%$ \\
\hline $\begin{array}{c}\text { Main channel, } \\
\text { bed armor }\end{array}$ & $0 \%$ & $3 \%$ & $\mathbf{9 7 \%}$ & $0 \%$ & $100 \%$ \\
\hline
\end{tabular}

The probability values indicated for the three main morphodynamic processes emphasize the suitability of $R e^{*}$ for the determination of the locally dominant grain size range in the bed load transport. On the other hand, the application of $R e_{p}$ suggests no clear classification way for the same categorization, when spatially varied bed material is present, such as at the investigated river reach. It can be seen that the higher the $R e^{*}$ the more dominant the gravel rate and less the sand motion. Note that similar behavior could be observed in Fig. 4. Furthermore, an important outcome of the probability analysis is that the $R e^{*}$ between 300 and 400 is indeed a critical range: below 300 the sand transport, above 400 the gravel motion dominates.

\section{Discussion}

A novel classification method is introduced in this paper, which is expected to distinguish the locally dominant sediment transport nature (sand or gravel) in a more accurate manner compared to other methods found in the literature, such as the Shields-Parker diagram, when investigating river morphodynamics on reach or local scale. As reported in previous studies, the dominant sediment transport nature, in rivers with uniform bed material, can be reliably determined as the function of the so called explicit particle Reynolds number $\left(R e_{p}\right)$, but yields less accurate estimations in cases, when the bed material composition shows strong variability even along shorter reaches. The authors of this paper believe that introducing the local bed shear stress values in the categorization method will provide better distinction for follow-up morphodynamic analysis.

Based on the available and accessible data, namely 70 bed material samples and related local bed shear stress values gathered both from recent own laboratory and field experiments, it could be confirmed that, instead of the utilization of the explicit particle Reynolds number $\left(\operatorname{Re}_{p}\right)$, or the application of characteristic grain sizes, e.g. $d_{50}, d_{90}$, the shear Reynolds number $\left(R e^{*}\right)$, in which the momentum forces at the river bed are represented by the shear velocity, is a more adequate parameter to assess the locally dominant sediment transport nature. Besides the own experimental data, it could also be shown, that the $R e^{*}$ based approach works very well for the laboratory and field data based on which the widely used van Rijn [20,32,33] and the Wilcock and Crowe [23] bed load formulas were validated: sand motion takes place at lower $(<\sim 300) R e^{*}$ range, while the coarser gravel dominated transport is indicated at higher $(>\sim 400) R e^{*}$ values. As another example, we assessed the datasets, consisting of 45 coupled bed shear stress $-d_{50}$ characteristic grain size value pairs from field measurements, published by Mueller et al. [43]. In that study, the median surface 
grain sizes of the gravel-bed streams and rivers were reported to vary between 0.027 and $0.21 \mathrm{~m}$, which indicates quite coarse bed material and armored bed surface. Accordingly, the calculated $R e^{*}$ are consequently high, all estimated $R e^{*}$ values exceed 400 .

Based on the data assessment introduced above, the following classification could be set up:

- $R e^{*}<\sim 300 \rightarrow$ sand transport dominates,

- $R e^{*}>\sim 400 \rightarrow$ gravel transport dominates,

- $\quad 300<R e^{*}<\sim 400 \rightarrow$ gravel accumulating and side bar formation is expected.

Besides the promising validation results, the theory must be further proven by direct bed load field measurements. Also noted, that the local bed load content is depends not only on the local bed material, but also on the arriving bed load material. This obvious effect is not taken into account by the introduced method. Additionally, the benchmark measurements were carried out at week bed load discharges. Thus, the validation needs to be extended to wider range of the flow regime. However, the authors believe that the presented classification means a meaningful progress in the investigation methods of the non-uniform bed load.

\section{Conclusion}

Based on the findings of this study, an improved understanding of the locally dominant bed load transport can be gained, which can contribute to the better implementation of different sediment transport investigation methods applied in large rivers. For instance, a well-known issue related to field sediment transport monitoring is the high uncertainty of direct bed load sampling methods. Having information on the local bed material and on the flow field, the $R e^{*}$ based approach can suggest where and what sort of sampling techniques would be the most suitable to collect reliable sediment information, eventually yielding a more cost-efficient and more accurate field procedure. The results can also contribute to the development of improved computational modeling tools. Indeed, instead of applying one specific empirical sediment transport formula in a simulation to calculate local bed load transport and related morphological changes, the $R e^{*}$ based approach can be utilized to distinguish between several formulas, each of them having a certain application range. For instance, as already mentioned above, the van Rijn model could provide better sediment transport estimation in sand dominated zones, whereas the Wilcock and Crowe model suits better to gravel dominated cases. Implementing these two models in a computational tool, the calculated local $R e^{*}$ could suggest which formula to apply locally.

\section{Acknowledgements}

This research was supported by the ÚNKP-17-3 and 17-4 New National Excellence Program of the Ministry of Human Capacities, which is highly appreciated, and was partly supported by MTA TKI of the Hungarian Academy of Sciences. Support of grant BME FIKP-VÍZ by EMMI is also kindly acknowledged.

\section{References}

1. Dey, S. Fluvial Processes: Meandering and Braiding. In Fluvial Hydrodynamics: Hydrodynamic and Sediment Transport Phenomena; Springer Berlin Heidelberg, 2014; pp. 529-562.

2. Leopold, B. L.; Wolman, M. G. River Channel Patterns: Braided, Meandering and Straight. Geol. Surv. Prof. Pap. 1957, 282.

3. Lane, E. W. A study of the shape of channels formed by natural streams flowing in erodible material. U.S. Army Corps Eng. Rep. 1957, 141.

4. Leopold, L. B.; Wolman, M. G. River meanders. Geol. Soc. Am. Bull. 1960, 71, 769-794.

5. Schumm, S. A. Evolution and response of the fluvial system, sedimentologic implications. SEPM Spec. Publ. 1981, 31, 19-29.

6. Jaeggi, M. N. R. Effect of Engineering Solutions on Sediment Transport. In Dynamics of Gravel-Bed Rivers; 
Billi, P., Hey, R. D., Thorne, C. R., Tacconi, P., Eds.; John Wiley \& Sons Ltd, 1992.

7. García, M. H. Sediment Transport and Morphodynamics. In Sedimentation engineering: processes, measurements, modeling, and practice, Manuals and reports on engineering practice; ASCE, Ed.; Reston, 2008; pp. 21-163.

8. Parker, G. Transport of Gravel and Sediment Mixtures. In Sedimentation Engineering; Garcia, M., Ed.; American Society of Civil Engineers, 2008; pp. 165-251 ISBN 978-0-7844-0814-8.

9. Schumm, S. A.; Dumont, J. F.; Holbrook, J. M. Active Tectonics and Alluvial Rivers; Cambridge, New York, Melbourne: Cambridge University Press, 2000; ISBN 0521661102.

10. Edward J. Hickin Fluid mechanics; Online course note, Chapter 4, Burnaby, BC, Canada, 2009;

11. Piton, G.; Recking, A. The concept of travelling bedload and its consequences for bedload computation in mountain streams. Earth Surf. Process. Landforms 2017, 42, 1505-1519, doi:10.1002/esp.4105.

12. Farkas-Iványi, K.; Guti, G. The Effect of Hydromorphological Changes on Habitat Composition of the Szigetköz Floodplain. ACTA Zool. Bulg. 2014, 7, 117-121.

13. Hankó, Z.; Starosolszky, Ö.; Bakonyi, P. Megvalósíthatósági tanulmány a Duna környezetének és hajózhatóságának fejlesztésére (Danube Environmental and navigation Project, Feasibility Study). Vízügyi Közlemények 1996, 78, 291-315.

14. Rákóczi, L. A Duna-meder sorsa Szap és Szob között (Destiny of the Danube channel between Szap and Szob). Vízügyi Közlemények 2000, 82, 262-280.

15. Goda, L. A Duna gázlói Pozsony-Mohács között (Shallows of the River Danube between Pozsony, Bratislava and Mohács. Vízügyi Közlemények 1995, 77, 71-102.

16. Török, G. T.; Baranya, S. Morphological investigation of a critical reach of the upper Hungarian Danube. Period. Polytech. Civ. Eng. 2017, 61, doi:10.3311/PPci.10530.

17. Baranya, S.; Józsa, J.; Török, G. T.; Ficsor, J.; Mohácsiné Simon, G.; Habersack, H.; Haimann, M.; Riegler, A.; Liedermann, M.; Hengl, M. A Duna hordalékvizsgálatai a SEDDON osztrák-magyar együttműködési projekt keretében (Introduction of the joint Austro-Hungarian sediment research under the SEDDON ERFE-project). Hidrológiai Közlöny 2015, 95, 41-46.

18. Észak-Dunántúli Vízügyi Igazgatóság Nagyvízi mederkezelési terv (High water river management plan) 01.nmt.02. (egyeztetési terv) - Duna 1809,76 - 1786,00 fkm; 2014;

19. Liedermann, M.; Gmeiner, P.; Pessenlehner, S.; Haimann, M.; Hohenblum, P.; Habersack, H. A Methodology for Measuring Microplastic Transport in Large or Medium Rivers. Water 2018, 10, doi:10.3390/w10040414.

20. van Rijn, L. C. Sediment Transport, Part I: Bed Load Transport. J. Hydraul. Eng. 1984, 110, 1431-1456, doi:10.1061/(ASCE)0733-9429(1984)110:10(1431).

21. Wilcock, P. R.; Crowe, J. C. Surface-based transport model for mixed-size sediment. J. Hydraul. Eng. 2003, 129, 120-128.

22. Fischer-Antze, T.; Rüther, N.; Olsen, N.; Gutknecht, D. Three-dimensional (3D) modeling of non-uniform sediment transport in a channel bend with unsteady flow. J. Hydraul. Res. 2009, 47, 670675, doi:10.3826/jhr.2009.3252.

23. Wilcock P.R.; Kenworthy S.T.; Crowe J.C. Experimental Study of the Transport of Mixed Sand and Gravel. Water Resour. Res. 2001, 37, 3349-3358.

24. Wilcock, P. R. A two-fraction model for the transport of sand/gravel mixtures. Water Resour. Res. 2002, 38, 1-12, doi:10.1029/2001WR000684.

25. Török, G. T.; Baranya, S.; Rüther, N. Three-Dimensional Numerical Morphological Modeling of 
Non-Uniform Sediment Transport and Bed Armoring Process. 2012.

26. Sziło, J.; Bialik, R. J. Grain Size Distribution of Bedload Transport in a Glaciated Catchment (Baranowski Glacier, King George Island, Western Antarctica). Water 2018, 10, doi:10.3390/w10040360.

27. Einstein, H. A. The Bed-Load Function for Sediment Transportation in Open Channel Flows; Washington, 1950;

28. Ashida, K.; Michiue, M. Study on hydraulic resistance and bedload transport rate in alluvial streams. Trans. Japan Soc. Civ. Eng. 1972, 206, 59-69.

29. Meyer-Peter, E.; Müller, R. Formulas for Bed-Load Transport; IAHSR 2nd meeting, Stockholm, 1948;

30. Shields, A. Application of Similarity Principles and Turbulence Research to Bed-Load Movement. Mitt. Preuss. Versuchsanst. Wasserbau Schiffbau 1936, 26, 47.

31. Baranya, S.; Józsa, J.; Török, G. T.; Rüther, N. A comprehensive field analysis of a river confluence. In River Flow 2012 - Proceedings of the International Conference on Fluvial Hydraulics; 2012; Vol. 1.

32. Fernandez Luque, R. Erosion and Transport of Bed-load Sediment, BSc Thesis, manuscript: Delft Technical University, 1974.

33. Fernandez Luque, R.; van Beek, R. Erosion and Transport of Bed-load Sediment. J. Hydraul. Res. 1976, 14, 127-144.

34. Török, G. T.; Baranya, S.; Rüther, N.; Spiller, S. Laboratory analysis of armor layer development in a local scour around a groin. In Proceedings of the International Conference on Fluvial Hydraulics, RIVER FLOW 2014; Taylor and Francis Group: Lausanne, 2014; pp. 1455-1462.

35. Detert, M.; Weitbrecht, V. User guide to gravelometric image analysis by BASEGRAIN. In Advances in river sediment research; Fukuoka, S., Nakagawa, H., Sumi, T., Zhang, H., Eds.; CRC Press, 2013 ISBN 9781138000629.

36. Kim, S. C.; Friedrichs, C. T.; Maa, J. P. Y.; Wright, L. D. Estimating bottom stress in tidal boundary layer from Acoustic Doppler velocimeter data. J. Hydraul. Eng. 2000, 126, 399-406, doi:10.1061/(ASCE)0733-9429(2000)126:6(399).

37. Cea, L.; Puertas, J.; Pena, L. Velocity measurements on highly turbulent free surface flow using ADV. Exp. Fluids 2007, 42, 333-348, doi:10.1007/s00348-006-0237-3.

38. Török, G. T. Methodological improvement of morphodynamic investigation tools for rivers with non-uniform bed material by, PhD Thesis, manuscript: Budapest Univerity of Technology and Economics, 2018.

39. Török, G. T.; Baranya, S. Morphological Investigation of a Critical Reach of the Upper Hungarian Danube. Period. Polytech. Civ. Eng. 2017, 61, 752-761, doi:https://doi.org/10.3311/PPci.10530.

40. Koris, K. Hidrológia II. (Hydrology II); 1. kiadás.; Class note (Egyetemi jegyzet): Budapest, Hungary, 2014; ISBN 978-963-12-0752-1.

41. EasyFit Professional 2015.

42. Aristizabal, R. J. Estimating the Parameters of the Three-Parameter Lognormal Distribution, FIU Electronic Theses and Dissertation, Florida International University, 2012.

43. Mueller, E. R.; Pitlick, J.; Nelson, J. M. Variation in the reference Shields stress for bed load transport in gravel-bed streams and rivers. Water Resour. Res. 2005, 41, doi:10.1029/2004WR003692.

(C) 2018 by the authors. Submitted for possible open access publication under the terms and conditions of the Creative Commons Attribution (CC BY) license (http://creativecommons.org/licenses/by/4.0/). 